\title{
Study on the Effect of Composition and Variation of Sn/Zn Cooling Media on Nickel Alloy Steel through Hot Forging and Austempering
}

\author{
S. Herbirowo 1, , M. Harimurti2, S. A. Chandra1, D. P. Utama', F. M. Ridlo1, Y. M. Zulaida², and B. Adjiantoro1 \\ ${ }^{1}$ Research Center for Metallurgy and Materials, Indonesian Institute of Sciences Gedung 470, Kawasan Puspiptek, Serpong 15314, Indonesia \\ ${ }^{2}$ Teknik Metalurgi, Fakultas Teknik, Universitas Sultan Ageng Tirtayasa, Banten, Indonesia
}

\begin{abstract}
Laterite steel with nickel content is expected to be a solution to overcome the lack of domestic steel availability and dependence on imports. This research was conducted to develop Nickel-Chromium-Molybdenum alloy steel used Grinding ball for cement industrial applications. Grinding ball is the one of imported steel products needed to be crushing and size reduction the ores or cement. In addition to import issues, grinding balls have a significant problem: their mechanical properties that do not meet SNI 1049 require the material to have a minimum hardness value of 45 HRC. In this study, the characteristics of Nickel alloy steel were investigated further through heat treatment of forgings heated at the austenitizing temperature of $950{ }^{\circ} \mathrm{C}$ and austempering with variations in the cooling medium of $\mathrm{S} / \mathrm{Zn}$ solution. The cooling medium was chosen because it has a melting temperature in the phase diagram area to form the bainite microstructure with complex and challenging characteristics, both of which are required in material for grinding ball applications. In particular, the hardness value that passed the SNI 1069 standard was the use of samples with a $\mathrm{Cr}$ Mo alloy of $1 \%$-wt with a hardness value of $45.92 \mathrm{HRC}$ for Sn Austemper and 48.07 HRC for Zn austemper.
\end{abstract}

ARTICLE HISTORY

Received: 2 June 2021

Revised: 12 October 2021

Accepted: 21 October 2021

KEYWORDS

Alloy steel

Grinding ball

Austempering

Hot forging

\section{INTRODUCTION}

Laterite iron ore contains nickel, which can be an alternative as a substitute for primary iron ore (hematite and magnetite) and iron sand. Laterite ores are widely found in the former South Kalimantan and Southeast Sulawesi [1], based on data compiled from the geological resource center in 2016. There were 214.63 tons of iron ore reserves with details of laterite iron ore reserves of 100.91 tons, primary iron ore 45.85 tons, and iron sand 67.87 tons [2]. As it is known, until now, the national steel consumption had not been fully fulfilled, so that some imports must be carried out to meet the national steel consumption. On the other hand, laterite ore with a nickel content of $0.8-1.5 \%$, processed into steel, will produce steel with nickel content reaching 2-3\% [3]. This content is a good added value considering that nickel can improve mechanical properties such as strength, ductility, and corrosion resistance [4]. Therefore, the solution for processing laterite ore into steel is one of the things that has the potential to be done, so it is hoped that laterite steel will be able to overcome the shortage of steel availability in various applications, such as raw materials for making grinding balls.

Grinding ball is one of the imported steel products that has not been produced domestically [5]. The availability of grinding balls plays an essential role in the mining and cement industries. Several studies were conducted to develop a laterite steel grinding ball for the application. From the initial study on the characteristics of laterite steel, it is known that the hardness value is only 117 HRB (49 HRC) in as-cast conditions (without alloy)[6]. Based on the SNI 1069 standard, the required material for grinding ball applications is alloy steel material with a minimum hardness value of 45 HRC. Various attempts to improve the mechanical properties of laterite steels have been carried out, one of them by Herbirowo and Romijarso. Their research revealed that the hardness of laterite steel increases with increasing austenitization temperature[7]. In addition, the strength and hardness of laterite steel can also be increased through the mechanical working method, as revealed by Herbirowo and Adjiantoro in their 2017 research which explained that the mechanical properties increase by increasing the percentage reduction in hot rolling. [8]. In addition to hot rolling variations, laterite steel's hardness and impact strength can also be increased through hot forging followed by an austemper process using oil media [9]. However, there are still shortcomings in the get-as level if the hard value gets higher than as-cast.

From various experiments on methods to improve the mechanical properties of lateritic steel, austempering heat treatment, and alloying elements were chosen because they can form bainite microstructures with complex characteristics with optimal energy absorption capabilities. In previous research, the addition of $\mathrm{Mo}$ and $\mathrm{Cr}$ to is well known as element which provide phase balance strengthening by facilitating the formation of bainit structure, and solid solution strengthening [10-11]. Furthermore, in several studies have reported that austempering process which leads to bainitic or mixed bainite-martensite microstructures provides a better combination of mechanical properties, especially strength and impact toughness[12]. In general, the salt solution is a medium used in the austempering process. However, the use of a saline solution is known to cause furnace equipment components and harmful gas emissions [13]. With these shortcomings, another alternative that can be used as an austemper medium was chosen, namely by using molten metal. 
This study investigates the effect of alloying elements and the hot forging-austemper method on microstructure and mechanical properties. Especially hardness to approach or exceed the typical hardness values of grinding balls.

\section{EXPERIMENTAL METHOD \\ Materials and Instruments}

The material used in this research is lateritic steel from casting with converting raw materials in the form of Nickel Pig Iron and mild steel scrap and FeCr; FeMo master alloy, then the results of the chemical composition characterization using the OES Spectrometer method is shown in Table 1.

The difference from the sample code A1-A3 is the addition of $\mathrm{Cr}$ and Mo alloys. for A1 the addition of $1 \% \mathrm{Mo}$, for A 2 the addition of $1 \% \mathrm{Cr}$ and $\mathrm{A} 3$ the addition of $1 \% \mathrm{Cr}$ and Mo alloys in material balance. The austenitizing process using muffle furnace before hot forging 50-100 tons. The sample characterization tools include hardness testing using the BREVETTI AFFRI Hardness Tester with Rock-well type $\mathrm{C}$ method. Impact testing using the Charpy method, abrasive testing using the pin on disk Taber Abrasion method ASTM D1044, ASTM D4060. Meanwhile, the microstructure observation from grinding, polishing and nital etching. For characterization using a MEIJI optical microscope with the calculation of grain size carried out ImageJ software as a measurement validation test.

\section{Method and Procedure}

Laterite steel ingots were cut to a size of $30 \times 30 \times 10 \mathrm{~cm}$. Then initial characterization was carried out on the samples to determine the microstructure and hardness values before being heat treated. The hot forging process are shown in Figure 1.

Samples that have been cut are then heated at a temperature of $1000^{\circ} \mathrm{C}$ for 2 hours, and then using mechanical hot forging is carried out range 50-100 tons until a 20\% reduction from $10 \mathrm{~cm}$ thick to $8 \mathrm{~cm}$ and followed by cutting based on the shape of the sample for impact and abrasive tests. Then the sample was austempered at a temperature of $950{ }^{\circ} \mathrm{C}$ with a holding time of 1.5 hours. The holding temperature during austempering is based on the melting temperatures of $\mathrm{Sn}$ and $\mathrm{Zn}$ metals, which are 300 and $500^{\circ} \mathrm{C}$, respectively. After the austempering process, the mechanical and metallographic tests were carried out.

Table 1. Chemical Composition of Laterite Steel Alloys

\begin{tabular}{ccccc}
\hline Element & As cast/NA (\%wt) & A1 (\%wt) & A2 (\%wt) & A3 (\%wt) \\
\hline $\mathrm{C}$ & 0,1556 & 0,2639 & 0,2811 & 0,2138 \\
$\mathrm{Cr}$ & 0,0265 & 0,1952 & 1,077 & 1,074 \\
$\mathrm{Mo}$ & 0,006 & 0,937 & 0,0073 & 0,9552 \\
$\mathrm{Ni}$ & 2,483 & 2,195 & 2,463 & 2,175 \\
$\mathrm{Si}$ & 0,601 & 0,398 & 0,3534 & 0,4674 \\
$\mathrm{Mn}$ & 0,4713 & 0,4268 & 0,3324 & 0,532 \\
$\mathrm{P}$ & 0,0005 & 0,0005 & 0,0005 & 0,0005 \\
$\mathrm{~S}$ & 0,0003 & 0,0003 & 0,0003 & 0,0003 \\
$\mathrm{Fe}$ & Bal. & Bal. & Bal. & Bal. \\
\hline
\end{tabular}

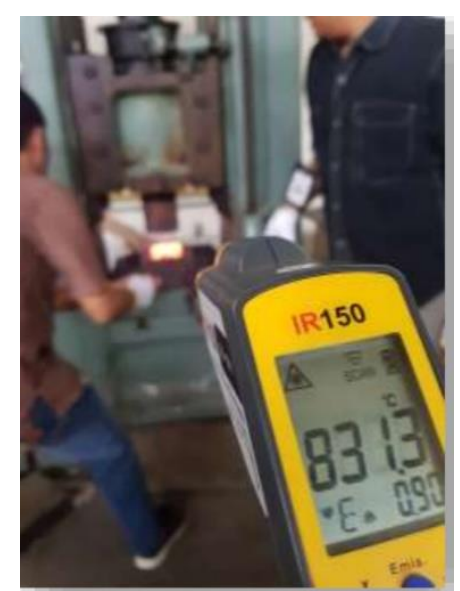

Figure 1. Hot forging process 


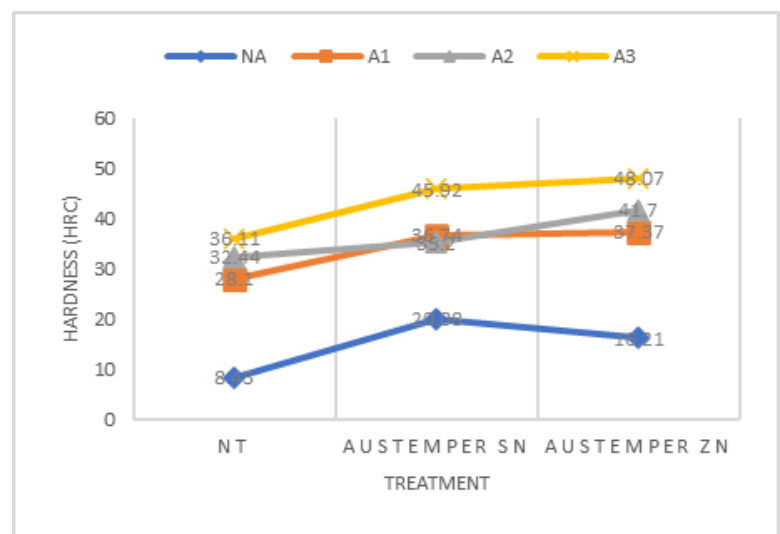

Figure 2. Alloys Hardness of various treatment

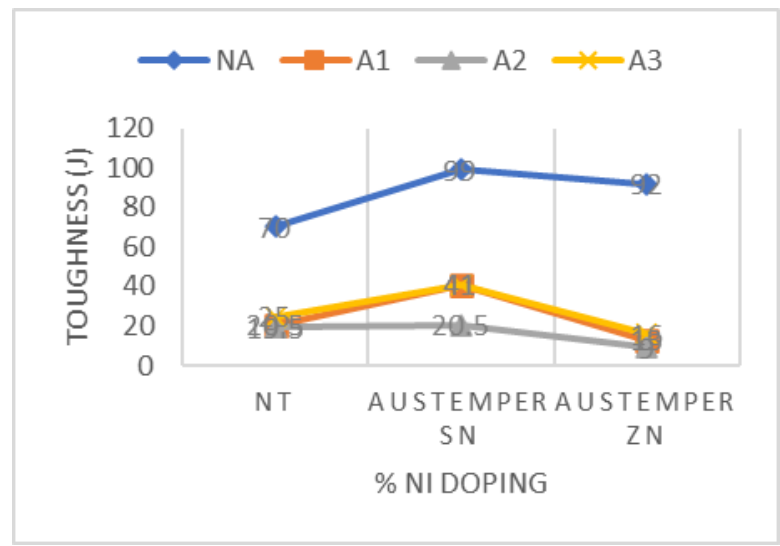

Figure 3. Alloys Toughness of various treatment

\section{RESULT AND DISCUSSION}

The effect of the austemper treatment on the hardness value is shown in Figure 2. In general, the austemper treatment tends to increase the hardness of the sample using either Sn or Zn molten media. The NT (Non-Heat treated) sample, which was used as a reference for the initial data, showed an increase in the value of hardness in all types of samples from 8.43 to 20.08 HRC

The addition of $\mathrm{Cr}$ and Mo elements, as well as the austempering process, may influence the hardness of sampel, as shown in Figure 2. It is known that the austempered sample with melted $\mathrm{Sn}$ has a holding temperature during cooling of $300{ }^{\circ} \mathrm{C}$, while the austempered sample with melted $\mathrm{Zn}$ has a holding temperature of $500{ }^{\circ} \mathrm{C}$. The sample NA, which contained no $\mathrm{Cr}$ or Mo alloying, has the lowest hardness compared to other 3 samples. For this sample, the hardness was increased at austempering temperature $300^{\circ} \mathrm{C}$ and subsequently declined at austempering temperature $500^{\circ} \mathrm{C}$. At lower temperature, the lower bainite structure is formed which has higher hardness. Whereas at higher temperature, the upper bainite structure has lower hardness [12].

The addition of alloying elements $\mathrm{Cr}$ and Mo to samples A1, A2 and A3 caused a significant increase in hardness compared to sample NA. The highest hardness was obtained in sample A3 with the combination addition of $\mathrm{Cr}$ and Mo, followed by sample A2 with the addition $\mathrm{Cr}$, and sampel A1 with the addition of Mo, respectively. In addition, the increase in austempering temperature also affects the increase of hardness in all samples, resulting the optimum hardness of 48.07 HRC at sample A3. Both of $\mathrm{Cr}$ and Mo have the same role to promote bainitic formation, increase its hardenability, and strength by solid solution strengthening mechanism [10]. This also is in agreement with Zhou et.al and Citrawati et.al[14], [15]. Furthermore, the addition of $\mathrm{Cr}$ and Mo elements also contributed in grain refinement which were consistent with the grain measurement results in all samples. According Chen et.al, this will generate refinement strengthening which affect the increasing of hardness in low-alloy bainitic steels[16].

In Figure 2 it can be analyzed that in general the austemper heat treatment through the liquid medium of $\mathrm{Sn}$ and $\mathrm{Zn}$ can increase the hardness slightly as well as the variation of the alloy. The element chromium in steel plays a role in lowering the critical cooling rate which is defined as the cooling rate at which ferrite precipitates begin to form. When a sample has a large amount of chromium, it can be assumed that the ferrite fraction is also high[18].

Figure 3 shows that the toughness value can be increased through austempering treatment. Figure 3 shows the effect of alloys and variations in the austempering process on the toughness of alloy steels. In general, unalloyed (NA) samples had higher toughness values than alloyed samples in all treatment variations. The toughness value of the NA sample increased from $70 \mathrm{~J}$ in the untreated condition to $99 \mathrm{~J}$ in the $\mathrm{Sn}$ austemper treatment, then decreased in the $\mathrm{Zn}$ austemper treatment. Interestingly, this trend was also seen in all samples with alloys, although there was a significant decrease in toughness values. The austemper process using an $\mathrm{Sn}$ melt has a more significant effect on the impact value than 
austemper with a $\mathrm{Zn}$ melt. This is because the austempered sample with melted Sn has a microstructure of lower bainite. On the other hand, chromium and molybdenum alloying elements affect decreasing the impact strength value in each treatment. According to Yamada, the Mo element plays a role in the formation of $\mathrm{Mo}_{2} \mathrm{C}$ carbide, where this carbide can increase the strength of the material but, on the other hand, reduce the toughness. [19].

The influence of alloys and variations in the wear-tempering process on the abrasive rate is shown in Figure 4, where the abrasive rate value is closely related to the hardness value. The austempering process with melted $\mathrm{Sn}$ influences decreasing the wear rate, where this is due to the formation of a miro structure in the form of lower bainite which has a high hardness value. In his research, Kim et al. mentioned that high hardness could reduce the wear rate or in other words, increase its abrasive resistance[20]. Meanwhile, the austemper treatment with melted $\mathrm{Zn}$ only decreased the wear rate in the A1 sample compared to the NA, A2 and A3 samples. Residual austenite on microstructure must be avoided in the final heat-treatment process. this is common in heat treatment processes with rapid cooling to form martensite [21]. One of the factors that can reduce the possibility of residual austenite is to increase the austenitization temperature [22]. Chromium and molybdenum elements have a decreasing effect on the value of the wear rate. In the austemper treatment with melted Sn, samples A1; A2 and A3 have lower wear rate values when compared to NA samples and A1 samples produce the lowest wear rate values of $0.35 \mathrm{mg} / \mathrm{cm} 2$. The decrease of wear rate in molybdenum is due to the lower bainite transformation temperature in the presence of molybdenum. This decrease in the bainite transformation temperature will suppress the formation of allotriomorphic ferrite and pearlite to produce a dominant phase of bainite with a bit of martensite.[23].

Figure 5 shows that the variations of the austemper process (with melted Sn or $\mathrm{Zn}$ ) affect the decrease in grain size in all sample variations. Sample A3 which underwent the austemper process with melted Zn had the most refined grains with a size of $3.802 \mu \mathrm{m}$. Austemper treatment with melted Sn can gradually reduce the grain size of the initial sample (Non-Treatment) from $\sim 58$ until $~ 5$ micron due to differences in the microstructure formed [24]. As can be seen in Figure 7 , the final microstructure of the sample changes when austempered, either into bainite (upper bainite, lower bainite, or granular bainite) or martensite. In addition, changes in grain size can also be influenced by chromium and molybdenum alloy elements. NA (Non-Alloy) samples always had larger grain sizes than samples A1, A2, and A3 in the untreated samples (NT) and the austempered samples with melted Zn. Meanwhile, the austempered NA sample with melted Sn experienced an anomaly where the grain size was smaller than that of the A1 sample. This is because the A1 sample produces a bainite microstructure with a greater density than the NA sample, which is possible. After all, the austemper process with melted Sn causes the phases in sample A1 to not transform into bainite. In samples with chromium alloys, molybdenum, or a combination of the two alloys experienced a decrease in grain size, where the smallest grain size was obtained in sample A3 (having a combination of chromium and molybdenum elements). The presence of these two elements can reduce the recrystallization rate of austenite which can lead to grain refinement. [10]

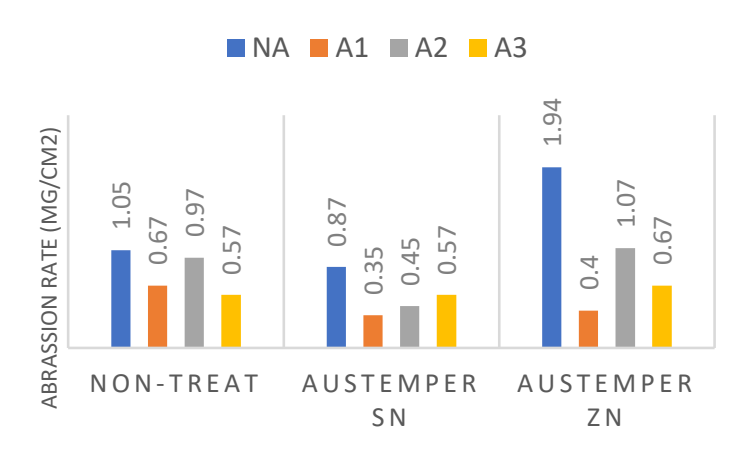

Figure 4. Alloy's abrasion rate of various treatment

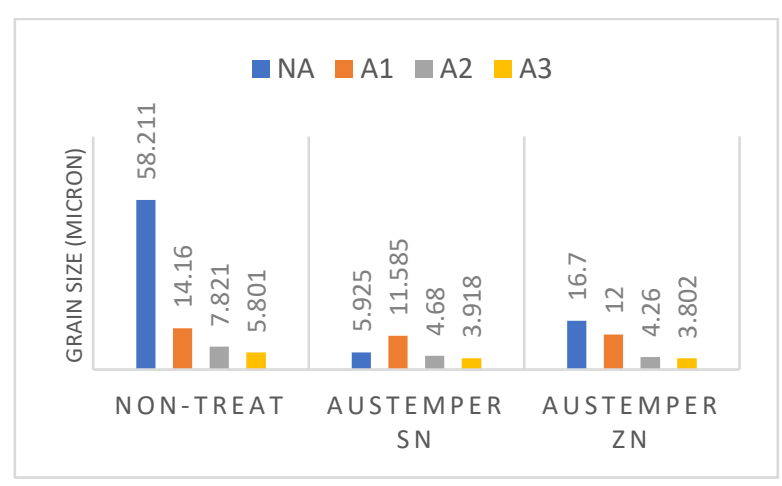

Figure 5. Alloys grain size of various treatment 

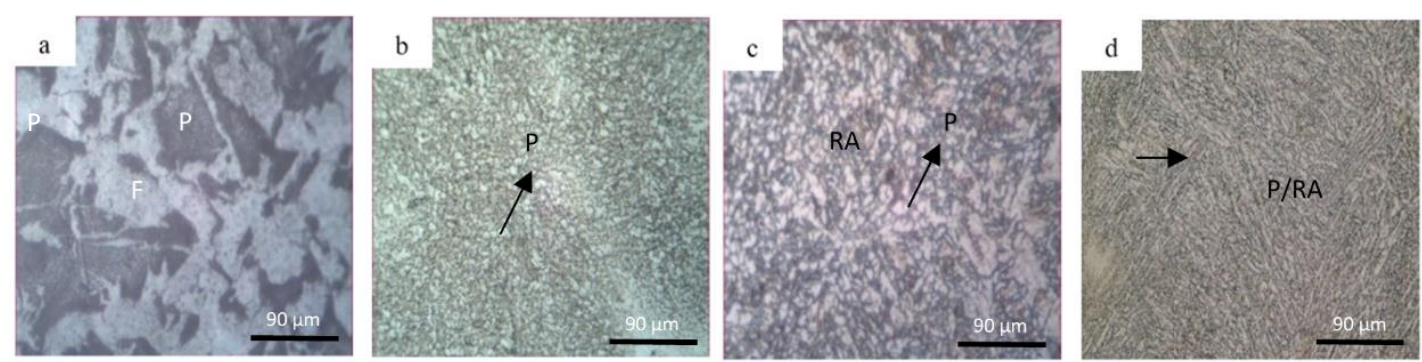

Figure 6. Microstructure of non- heat treat a)NA; b)A1; c)A2; and d)A3 on magnification 500x
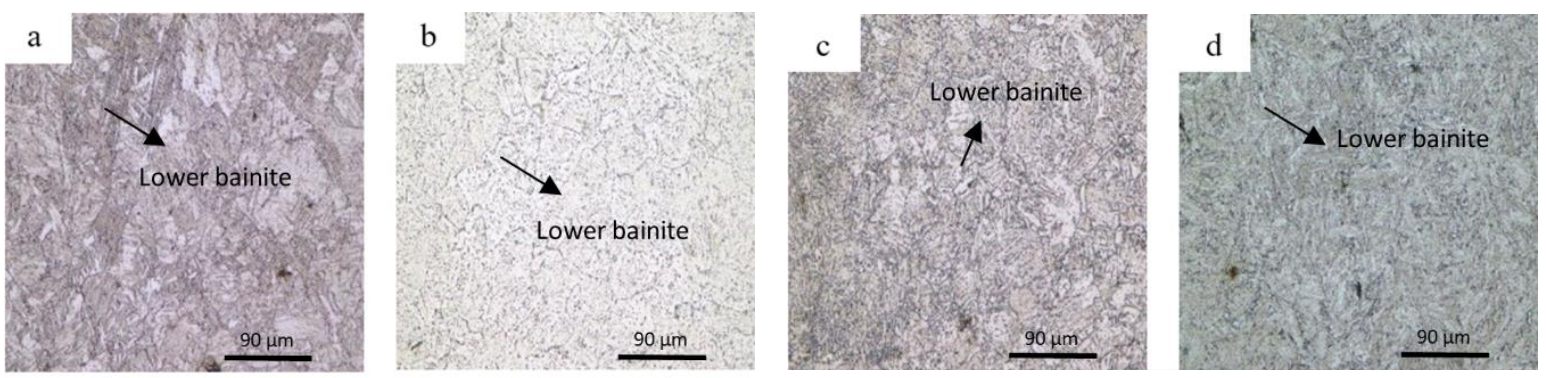

Figure 7. Microstructure of austempering Sn a) NA; b)A1; c)A2; and d)A3
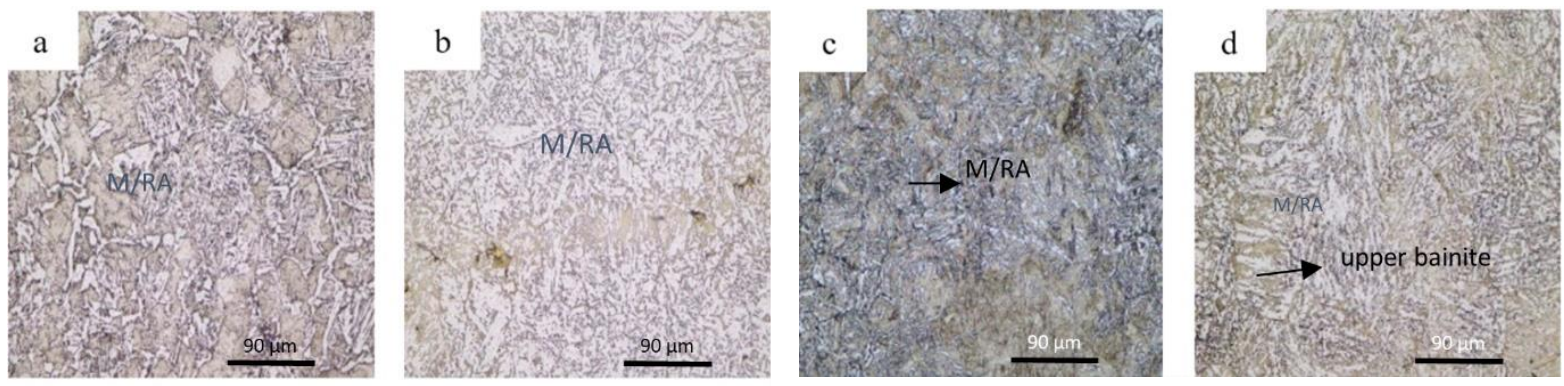

Figure 8. Microstructure of austemper Zn a)NA; b)A1; c)A2; and d)A3

Figure 6a shows the predominant microstructure of pearlite $(\mathrm{P})$ ferrite $(\mathrm{F})$ and retained austenite (RA)with differences in grain size due to the different alloys contained in each sample. Figure 7-8 shows the changes in the microstructure formed from the sample with various alloys and austemper treatment. it can be observed the changes in microstructure after the sample is austempered with melted $\mathrm{Sn}$ and melted $\mathrm{Zn}$ and the difference when the sample contains $\mathrm{Cr}$ or Mo alloy elements either separately or combined in the sample. The phases produced by austemper with Sn molten are lower bainite would increase the strengthening material significantly. Nevertheless, while the phases produced by austemper with melted $\mathrm{Zn}$ are upper bainite, residual austenite(RA), and martensite (M) as shown in Figure 8. The two samples have in common that there is a content of $1 \% \mathrm{Cr}$. Cr can increase the volume of homogenization and increase the amount of fine martensite on the final microstructure after heat treatment [25].

\section{CONCLUSION}

Chromium and molybdenum alloys can be affected the mechanical properties of nickel alloy steel. In particular, the hardness value that passed the SNI 1069 standard was the use of samples with a Cr-Mo alloy of 1\% wt with a hardness value of 45.92 HRC for Sn Austemper and 48.07 for $\mathrm{Zn}$ austemper. Sn molten quench will produce lower bainite, upper bainite, and martensite microstructures with an average grain size of 5.357 microns. Zn molten quench media will produce upper bainite microstructures with residual austenite, and martensite with an average grain size of 9.25 micron. A1 samples produce the lowest wear rate values of $0.35 \mathrm{mg} / \mathrm{cm}^{2}$

\section{ACKNOWLEDGEMENT}

We would like to thank the LIPI, BRIN, UNTIRTA and all researchers and technicians involved in supporting the implementation of this research and manuscript. 


\section{REFERENCES}

[1] Nurhakim, M. U. Dwiatmoko, N.H. Romla, and M. Adip. "Identifikasi Potensi Endapan Bijih Besi Laterit Di Bagian Tengah Pulau Sebuku, Provinsi Kalimantan Selatan.” Info-Teknik, vol. 12, no. 2, pp. 1-6, 2016.

[2] Direktorat Jenderal Mineral dan Batubara Kementerian Energi dan Sumberdaya Mineral (2020). Laporan Kinerja Tahun 2020. [On-line] 53(9). Available: https://www.esdm.go.id/assets/media/content/content-lapoan-kinerja-kesdm-2020.pdf.

[3] M.Y. Hasbi, D.P. Malau, B. Adjiantoro, and Jajang. "Pengaruh Variasi Reduksi Terhadap Kekerasan Dan Struktur Mikro Baja Laterit Melalui Pengerolan Panas.” in Seminar Nasional Sains dan Teknologi, 2016, pp. 1-8.

[4] G.E. Totten. Steel Heat Treatment Handbook, 2nd ed. Taylor and Francis, 2006.

[5] A. Shofi, W. Astuti, and F. Nurjaman. "Besi Tuang Putih Paduan Krom Tinggi Hasil Thermal Hardening Untuk Aplikasi Grinding Ball.” Jurnal Metalurgi, vol. 28, pp. 177-184, Des. 2013.

[6] B. Adjiantoro, A. Jamali, R. Binudi, and M. Y. Hasbi. "Proses Pengerjaan Dan Perlakuan Panas Characteristics of Mechanical Properties for Steel Laterite Through Hot Working and Heat Treatment Process. ” Jurnal Teknologi Bahan dan Barang Teknik, vol. 6(2), pp. 75-80, 2016.

[7] S. Herbirowo and T. B. Romijarso. "Pengaruh Variasi Suhu Austenisasi Pada Pembuatan Material Fasa Ganda Baja Laterit." in Semin. Nas. Sains dan Teknologi, 2017, pp. 1-2.

[8] S. Herbirowo and B. Adjiantoro. "Characteristic of Mechanical and Morphological Properties of Heat Rolled Laterite Steel with Variety of Size Reduction.” Solid State Phenomena, vol. 266, 2017.

[9] S. Herbirowo, B. Adjiantoro, F. Citrawati, and Jajang. "Karakteristik Sifat Mekanik Dan Struktur Mikro Baja Laterit Paduan NiCr-Mn Hasil Tempa Panas Dengan Variasi Beban Tempa.” Metalurgi, vol. 33, pp. 1-8, 2018.

[10] A. Kostryzhev, N. Singh, L. Chen, C. Killmore, and E. Pereloma. "Comparative Effect of Mo and Cr on Microstructure and Mechanical Properties in NbV-Microalloyed Bainitic Steels.” Metals (Basel)., vol. 8, no. 2, 2018.

[11] H. Mohrbacher. "Molybdenum Alloying - More than Hardenability." Advances in Manufacturing, vol. 8, pp. 15-34, 2020.

[12] A. Morri, L. Ceschini, M. Pellizzari, C. Menapace, F. Vettore, and E. Veneri. "Effect of the Austempering Process on the Microstructure and Mechanical Properties of 27MnCrB5-2 Steel.” Archives of Metallurgy and Materials, vol. 62, no. 2, pp. 643$651,2017$.

[13] B. V. de Souza, T. M. Ribeiro, A. Francois, and C. A. dos Santos. "Austempering Heat Treatments of Ductile Iron Using Molten Metal Baths.” Material Manufacturing Process, vol. 33, no. 15, pp. 1667-1673, 2018.

[14] F. Citrawati, S. A. Chandra, D. Irawan, and J. T. Wardono. "Effects of Cr Addition and Cold Deformation on the Mechanical Properties of a FeNi Bainitic Steel.” Advances in Materials and Processing Technologies, vol. 00, no. 00, pp. 1-8, 2020.

[15] M. Zhou, G. Xu, J. Tian, H. Hu, and Q. Yuan. "Bainitic Transformation and Properties of Low Carbon Carbide-Free Bainitic Steels with Cr Addition.” Metals (Basel)., vol. 7, no. 7, pp. 1-13, 2017.

[16] Z. Chen, J. Qi, H. Liu, L. Sun, H. Wei, and G. Wang. "Bainitic Transformation and Mechanical Properties of Low-Carbon High-Strength Bainitic Steels with Mo Addition.” Journal of Materials Engineering and Performance, vol. 29, no. 4, pp. 2428-2439, 2020. 